\title{
Management Aspects of Production Cost Accounting in Horse Breeding
}

\author{
Klychova G. S. ${ }^{1,2}$, Zakirova A. R. ${ }^{2}$, Zakirov Z. R. ${ }^{2} \&$ Valieva G. R. ${ }^{2}$ \\ ${ }^{1}$ Kazan Federal University, Institute of Management, Economics and Finance, Kazan, 420008, Russia \\ ${ }^{2}$ Kazan State Agrarian University Kazan, 420015, Russia \\ Correspondence: Valieva G. R., Kazan State Agrarian University Kazan, 420015, Russia. Tel: 7-987-275-4848. \\ E-mail:kgaukgs@mail.ru
}

Received: March 19, 2015 Accepted: March 31, 2015 Online Published: April 30, 2015

doi:10.5539/ass.v11n11p308 URL: http://dx.doi.org/10.5539/ass.v11n11p308

\begin{abstract}
The particular management accounting lines are considered in the present paper, based on the state and current practice of production cost accounting study and calculation of production cost of horse breeding in the analyzed companies, to help the enterprise management in making reasonable decisions regarding maintenance of cost management in the given industry. The criteria of breakeven point, marginal income, and safety edge can be used for production planning, decision-making on pricing for prediction of enterprise development, in particular, the selection of efficient management strategy of benefits and costs. Having analyzed the possible strategies in management of benefits, costs, one can determine the best options for management decisions (increase of price and sales volume of koumiss).
\end{abstract}

Keywords: management accounting, "direct costing", marginal revenue, forecasting, strategy

\section{Introduction}

Management process in modern conditions of the enterprise provided with complete financial and economic independence becomes greatly complicated. Simultaneously, the challenges facing the system of accounting are also changed. Financial accounting is not able to provide with full operative information necessary for planning and control as well as for decision-making in non-standard economic situations. These data can be obtained only in the framework of management accounting.

At present in horse breeding, a system of full inclusion of expenses in production cost is used. This system is traditional and includes all expenditures of the company associated with production and sales of horse breeding products (Nixon, 2012). Accounting as to total cost is important in determining the financial performance of the company, charging taxes. However, it does not provide all the information necessary for effective cost management. Therefore, we offer the system of reduced cost "direct costing" to improve accounting.

\section{Theory}

Cost accounting system "direct costing» is intended to include in the cost of production and ending stocks estimate only variable production costs and allocation on financial result of the total amount of fixed costs without distribution by product types. This creates a limited (partial) cost of products (works, services), which determines the lower limit of price. Undoubtedly, this approach is necessary in conditions when the price is influenced by supply and demand, i.e. establishing the market price (Hopwood, 2008; Soin \& Collier, 2013).

The purpose of this method is increasing the speed of decision-making on pricing and possibility of analyzing the relationship of the costs, volume of production (sales) of products and profit (CVP-analysis) as well as analysis of break-even point. The main principle of operational analysis is the classification of costs into variable and fixed ones (Ittner \& Larcker, 2002; Matsui, 2013). Such analysis, as the main tool for operational planning, is the search for the optimal combination between the variable costs per unit of output, fixed costs, sales volume and price. The analysis allows us to find a point of equilibrium (the breakeven point), in which the total amount of revenue is equal to total cost. When selling products below the breakeven point, the enterprise receives damages. The main concept of "direct costing" is that of "marginal profit", which is the income received by the company after compensation of all variable costs (Bebbington \& Thomson, 2013; Quinn, 2014).

Important advantages of "direct costing" (Bourne, Melnyk, Bititci, Platts, \& Andersen, 2014; Janke, Matthias, \& Mahlendorf, 2014): 
- Provided in its framework cost limiting only by direct costs sufficiently simplifies regulation, planning, accounting and control, reduces the complexity and amount of payment transactions, as there is no procedure for allocation of fixed costs as to product type;

- Accounting and control of indirect costs are improved, since their amount for that particular period is shown in financial statements as a separate line, which clearly shows their impact on profit margins;

- in "direct costing" system one can use elements of "direct cost" system in the category of flexible budgets and standard costs, this greatly increases the overall level and quality of elements of production and other costs control;

- On the basis of information obtained by using "direct costing" system one can make a variety of operational decisions on farm management, namely implement effective pricing policy, find more favorable combination of volume and price, determine the break-even point.

\section{Results}

Because if the company produces several types of products, and the amount of fixed costs is common, then for farm purposes the marginal income calculation will be more appropriate, which allows us to determine the efficiency of individual products within the enterprise. Let us consider a system of limited cost accounting on the basis of marginal income on the example of koumiss farm of "YYY" LLC.

The calculations in Table 1, allow us to give assessment of production efficiency of individual types of products. The most efficient is koumiss production and sale of young horses, where the marginal profit is $2,956.43$ thousand rubles.

Table 1. Calculation of marginal income as to products of horse breeding at koumiss farm of "YYY" LLC for 20XX, thousand rubles

\begin{tabular}{|c|c|c|c|c|c|}
\hline \multirow{2}{*}{ Name of parameters } & \multirow{2}{*}{ General data } & \multicolumn{3}{|c|}{ Types of products obtained } & \multirow{2}{*}{ Total } \\
\hline & & Koumiss & Horse meat & Young horses & \\
\hline 1. Breeding mare stock, head & 145 & $\mathrm{x}$ & $\mathrm{x}$ & $\mathrm{x}$ & $\mathrm{x}$ \\
\hline 2. Population of young horses, head & 180 & $\mathrm{x}$ & $\mathrm{x}$ & $\mathrm{x}$ & $\mathrm{x}$ \\
\hline 3. Stallions, fattening, head & 19 & $\mathrm{x}$ & $\mathrm{x}$ & $\mathrm{x}$ & $\mathrm{x}$ \\
\hline 4. Mare milk, produced, $\mathrm{kg}$ & 145967 & $\mathrm{x}$ & $\mathrm{x}$ & $\mathrm{x}$ & $\mathrm{x}$ \\
\hline 5. Yield per forage mare, $\mathrm{kg} /$ head & 1007 & $\mathrm{x}$ & $\mathrm{x}$ & $\mathrm{x}$ & $\mathrm{x}$ \\
\hline 6. Obtained gain, $\mathrm{c}$. & 377,09 & $\mathrm{x}$ & $\mathrm{x}$ & $\mathrm{x}$ & $\mathrm{x}$ \\
\hline 7. Daily gain, $g$ & 582 & $\mathrm{x}$ & $\mathrm{x}$ & $\mathrm{x}$ & $\mathrm{x}$ \\
\hline 8. Obtained offshoot, head & 127 & $\mathrm{x}$ & $\mathrm{x}$ & $\mathrm{x}$ & $\mathrm{x}$ \\
\hline 9. Annual culling, $\%$ & 15 & $\mathrm{x}$ & $\mathrm{x}$ & $\mathrm{x}$ & $\mathrm{x}$ \\
\hline 10. Produced, bottles & $\mathrm{x}$ & 237668 & $\mathrm{x}$ & $\mathrm{x}$ & $\mathrm{x}$ \\
\hline 11. bottles sold & $\mathrm{x}$ & 237668 bot. & $2850 \mathrm{~kg}$ & 77 head & $\mathrm{x}$ \\
\hline 12. average selling price per unit & $\mathrm{x}$ & 30,47 & 67,52 & $69,87 \mathrm{rub} / \mathrm{kg}$ & $\mathrm{x}$ \\
\hline 13. Revenue, thousand rubles & $\mathrm{x}$ & 7241,1 & 192,4 & 1871,9 & 9305,4 \\
\hline \multicolumn{6}{|l|}{ 14. Variable costs, th.: } \\
\hline - Salary with benefits; & $\mathrm{x}$ & 456,51 & 37,02 & 187,16 & 680,69 \\
\hline - Biologics & $\mathrm{x}$ & 1,80 & 0,15 & 0,63 & 2,58 \\
\hline - Zootechnic and veterinary care & $\mathrm{x}$ & 18,41 & 1,47 & 6,54 & 26,42 \\
\hline - mare milk; & $\mathrm{x}$ & 3114,56 & $\mathrm{x}$ & $\mathrm{x}$ & 3114,56 \\
\hline - feed; & $\mathrm{x}$ & $\mathrm{x}$ & 175,39 & 1157,37 & 1332,76 \\
\hline - raw materials; & $\mathrm{x}$ & 365,28 & 29,62 & 128,05 & 502,95 \\
\hline - heating; & $\mathrm{x}$ & 20,99 & 1,70 & 7,36 & 30,05 \\
\hline - electricity; & $\mathrm{x}$ & 87,09 & 7,06 & 30,52 & 154,72 \\
\hline - glass bottles; & $\mathrm{x}$ & 414,64 & $\mathrm{x}$ & $\mathrm{x}$ & 414,64 \\
\hline - other materials; & $\mathrm{x}$ & 15,41 & 1,23 & 5,40 & 22,04 \\
\hline - services of tractors & $\mathrm{x}$ & 18,75 & 1,52 & 6,71 & 26,98 \\
\hline - other services; & $\mathrm{x}$ & 11,00 & 34,35 & 55,67 & 71,02 \\
\hline Total variable costs, th. rubles & $\mathrm{x}$ & 4524,05 & 239,51 & 1585,41 & 6348,97 \\
\hline 15. Marginal income, th. rubles & $\mathrm{x}$ & 2717,05 & $-47,11$ & 286,49 & 2956,43 \\
\hline 16. margin per unit., rub & $\mathrm{x}$ & 11,43 & $-16,53$ & 10,69 & $\mathrm{x}$ \\
\hline \multicolumn{6}{|l|}{ 17. Fixed costs, th. rub: } \\
\hline - of general production; & $\mathrm{x}$ & $\mathrm{x}$ & $\mathrm{x}$ & $\mathrm{x}$ & 645,72 \\
\hline - of general farm; & $\mathrm{x}$ & $\mathrm{x}$ & $\mathrm{x}$ & $\mathrm{x}$ & 1023,95 \\
\hline - Commercial & $\mathrm{x}$ & $\mathrm{x}$ & $\mathrm{x}$ & $\mathrm{x}$ & 94,66 \\
\hline Total fixed costs, th. rub & $\mathrm{x}$ & $\mathrm{x}$ & $\mathrm{x}$ & $\mathrm{x}$ & 1764,33 \\
\hline 18. Operating profit & $\mathrm{x}$ & $\mathrm{x}$ & $\mathrm{x}$ & $\mathrm{x}$ & 1192,10 \\
\hline
\end{tabular}


One of the main objectives of management accounting is to collect and compile the information needed to make sound management decisions.

Based on the information of management accounting the problems of operative and perspective character are solved. Operational tasks include determining the break-even point, production planning, making decisions on pricing. The objectives of the forward-looking statements, those having a long-term strategic importance are: investment, restructuring of business, whether to develop new products (Safiullin, Klychova, \& Zakirova, 2014; Ferreira \& Otley, 2009).

One of the main types of management decisions on the basis of calculations of marginal revenue is carrying out the break-even analysis. To calculate the breakeven point for koumiss and youngsters horses are used the data of Table 1.

Sales volume of koumiss at breakeven point $=1764330: 11,43=154,359$ bottles, or in cash $154,559 \times 30,07=$ 4641575,13 rub.

Sales volume of young horses at breakeven point $=81690: 10.69=7641 \mathrm{~kg}$ or, in monetary terms, $7641 \times 69,87$ $=533927,06$ rubles.

To make advanced decisions the coefficient of marginal revenue is calculated. Profit margin per 1 bottle of koumiss and $1 \mathrm{~kg}$ of young horses is 11.43 and 10.69 rubles, correspondingly; sales revenue is 30.47 rubles for one bottle of koumiss and $69.87 \mathrm{rub} / \mathrm{kg}$ for young horses. Consequently, the ratio of marginal profit and revenue is $37.52 \%$ for koumiss and $15.30 \%$ for young horses. This means that for each 100 rub of realization the profit margin is 37.52 rubles and 15.30 rub, correspondingly.

Thus, having planned the sales revenue of products, one can determine the size of the expected marginal revenue. Suppose that the company plans to get revenue from the sale of koumiss 7654380 rubles and from the sale of young horses - 2050000 rubles, then this amount will match the profit margin of 2910195 rubles and 313,650 rubles, correspondingly.

To determine the operating profit (profit before tax) we deduct from this amount the calculated total fixed costs:

- for koumiss: $2910195-764330=1145865$ rubles,

- for young horses: $313,650-81,690=231,960$ rubles.

Thus, in the planned total income of 7654380 rubles as to koumiss and 2050000 rubles for young horses the profit will be 1145865 rubles and 231,960 rubles, correspondingly.

These calculations allow us to determine the security zone (stock of safety).

Safety edge, $\%=(($ planned sales revenue - break even point $) /$ planned sales revenue $) * 100 \%$

Substituting the corresponding numerical values in formula 1 , we get $\frac{7654380-4641575,13}{7654380} \times 100 \%=\frac{3012804,87}{7654380} \times 100 \%=39,36 \%$ as to koumiss and $13.94 \%$ as to young horses.

Thus, by these percent amount the volume of sales may be decreased before the company incurs a loss. If enterprise has a positive stock of safety, its profit is given by

$$
\text { Profit }=\text { Margin of Safety } \times \text { Margin profit per unit of product }
$$

Profit for koumiss is: $39,36 \times 11,43=4,49 \mathrm{rub} /$ bottle. That is, any change in the volume of sales leads to even more pronounced change in profit. This relationship is designated as the effect of operating leverage. Power of operating leverage shows the percentage change of profit, if revenue change is one percent.

Strength of operating leverage $=$ Margin Profit $/$ Profit $=($ Revenue - Variable Costs $) /$ Profit $=($ Profit + Fixed costs) / Profit

The strength of operating leverage is: $(11,43 \div 4,49)=2,54$. Consequently, if the next month revenues from koumiss increase by $10 \%$, profits will increase accordingly by $25.4 \%$.

By specifying the conditions of proposed sales one can set the minimum amount of variable and fixed costs, which can be withstood by the operation. Suppose one needs to implement for the year 248,500 bottles of koumiss. Having denoted the price by X, we get:

$248500 \times \times 19.03=248.500+1764330$

$\mathrm{X} 248,500=6,493,285$ 
$\mathrm{X}=26.13$ rubles

Thus, the organization will earn profit, selling one bottle of koumiss at a price of above 26.13 rubles under given conditions.

The maximum amount of the fixed and variable costs, which the company will be able to cover for the planned volume of production, is: $248,500 \times 30,47=7571,795$ rubles.

For a clearer presentation of the calculations performed for accounting and decision-making on the basis of marginal income, we have developed the management document "Calculating the marginal revenue as to product in productive horse breeding".

Table 2. Calculation of marginal income for horse breeding products of koumiss farm for 20XX.

\begin{tabular}{|c|c|c|c|c|c|}
\hline \multirow{2}{*}{ Name of parameters } & \multirow{2}{*}{ General data } & \multicolumn{3}{|c|}{ Types of products obtained } & \multirow{2}{*}{ - Total } \\
\hline & & Koumiss & Horse meat & Young horses & \\
\hline 1. Breeding mare stock, head & 145 & $\mathrm{x}$ & $\mathrm{x}$ & $\mathrm{x}$ & $\mathrm{x}$ \\
\hline 2. Population of young horses, head & 180 & $\mathrm{x}$ & $\mathrm{x}$ & $\mathrm{x}$ & $\mathrm{x}$ \\
\hline 3. Stallions, fattening, head & 19 & $\mathrm{x}$ & $\mathrm{x}$ & $\mathrm{x}$ & $\mathrm{x}$ \\
\hline 4. Mare milk, produced, $\mathrm{kg}$ & 145967 & $\mathrm{x}$ & $\mathrm{x}$ & $\mathrm{x}$ & $\mathrm{x}$ \\
\hline 5. Yield per forage mare, $\mathrm{kg} / \mathrm{head}$ & 1007 & $\mathrm{x}$ & $\mathrm{x}$ & $\mathrm{x}$ & $\mathrm{x}$ \\
\hline 6. Obtained gain, c. & 377,09 & $\mathrm{x}$ & $\mathrm{x}$ & $\mathrm{x}$ & $\mathrm{x}$ \\
\hline 7. Daily gain, $g$ & 582 & $\mathrm{x}$ & $\mathrm{x}$ & $\mathrm{x}$ & $\mathrm{x}$ \\
\hline 8. Obtained offshoot, head & 127 & $\mathrm{x}$ & $\mathrm{x}$ & $\mathrm{x}$ & $\mathrm{x}$ \\
\hline 9. Annual culling, $\%$ & 15 & $\mathrm{x}$ & $\mathrm{x}$ & $\mathrm{x}$ & $\mathrm{x}$ \\
\hline 10. Produced, bottles & $\mathrm{x}$ & 237668 & $\mathrm{x}$ & $\mathrm{x}$ & $\mathrm{x}$ \\
\hline 11. bottles sold & $\mathrm{x}$ & 237668 bot. & $2850 \mathrm{~kg}$ & 77 head. & $\mathrm{x}$ \\
\hline 12. average selling price per unit & $\mathrm{x}$ & 30,47 & 67,52 & $69,87 \mathrm{rub} / \mathrm{kg}$ & $\mathrm{x}$ \\
\hline 13. Revenue, thousand rubles & $\mathrm{x}$ & 7241,1 & 192,4 & 1871,9 & 9305,4 \\
\hline \multicolumn{6}{|l|}{ 14. Variable costs, th.: } \\
\hline - Salary with benefits; & $\mathrm{x}$ & 456,51 & 37,02 & 187,16 & 680,69 \\
\hline - Biologics & $\mathrm{x}$ & 1,80 & 0,15 & 0,63 & 2,58 \\
\hline - Zootechnic and veterinary care & $\mathrm{x}$ & 18,41 & 1,47 & 6,54 & 26,42 \\
\hline - mare milk; & $\mathrm{x}$ & 3114,56 & $\mathrm{x}$ & $\mathrm{x}$ & 3114,56 \\
\hline - feed; & $\mathrm{x}$ & $\mathrm{x}$ & 175,39 & 1157,37 & 1332,76 \\
\hline - raw materials; & $\mathrm{x}$ & 365,28 & 29,62 & 128,05 & 502,95 \\
\hline - heating; & $\mathrm{x}$ & 20,99 & 1,70 & 7,36 & 30,05 \\
\hline - electricity; & $\mathrm{x}$ & 87,09 & 7,06 & 30,52 & 154,72 \\
\hline - glass bottles; & $\mathrm{x}$ & 414,64 & $\mathrm{x}$ & $\mathrm{x}$ & 414,64 \\
\hline - other materials; & $\mathrm{x}$ & 15,41 & 1,23 & 5,40 & 22,04 \\
\hline - services of tractors & $\mathrm{x}$ & 18,75 & 1,52 & 6,71 & 26,98 \\
\hline - other services; & $\mathrm{x}$ & 11,00 & 34,35 & 55,67 & 71,02 \\
\hline Total variable costs, th. rubles & $\mathrm{x}$ & 4524,05 & 239,51 & 1585,41 & 6348,97 \\
\hline 15. Marginal income, th. rubles & $\mathrm{x}$ & 2717,05 & $-47,11$ & 286,49 & 2956,43 \\
\hline 16. Margin per unit, rub & $\mathrm{x}$ & 11,43 & $-16,53$ & 10,69 & $\mathrm{x}$ \\
\hline \multicolumn{6}{|l|}{ 17. Fixed costs, th. rub: } \\
\hline - of general production; & $\mathrm{x}$ & $\mathrm{x}$ & $\mathrm{x}$ & $\mathrm{x}$ & 645,72 \\
\hline - of general farm; & $\mathrm{x}$ & $\mathrm{x}$ & $\mathrm{x}$ & $\mathrm{x}$ & 1023,95 \\
\hline - Commercial & $\mathrm{x}$ & $\mathrm{x}$ & $\mathrm{x}$ & $\mathrm{x}$ & 94,66 \\
\hline Total fixed costs, th. rub & $\mathrm{x}$ & $\mathrm{x}$ & $\mathrm{x}$ & $\mathrm{x}$ & 1764,33 \\
\hline 18. Operating profit & $\mathrm{x}$ & $\mathrm{x}$ & $\mathrm{x}$ & $\mathrm{x}$ & 1192,10 \\
\hline 19. Break-even point (p17/ p16) & $\mathrm{x}$ & 154,36 & - & 165,04 & $\mathrm{x}$ \\
\hline 20.Safety edge, $\%$ & $\mathrm{x}$ & & & & \\
\hline 21. Manufacturing leverage & $\mathrm{x}$ & & & & \\
\hline
\end{tabular}

This form of the document is used to calculate the margin profit for products manufactured by the koumiss farm. New columns can be added in this document, when comparing planned and actual performance. The value of the marginal profit can be used to compare the efficiency of individual products manufacturing, finding the break-even point, edge security, analysis of variable and fixed costs and calculation of the optimal production program.

\section{Conclusions}

Thus, the need in integration of various elements of management accounting in a single system, supporting cost-considered management decision making, increase of productivity and competitiveness, is obvious in the 
current economic environment for effective management of agricultural enterprise and its existence in strict competitive environment, including the international level. In practice, some elements of management accounting, as a rule, are used in enterprises. It is important that these elements should be combined into the overall structure, aimed at achieving a specific result. Management accounting system, which is one of the most effective tools for planning and forecasting, operational control of efficiency of enterprise resources use, increase of its attractiveness, is a greatly complicated diverse system characterized by unity and correlation with external environment, structure, hierarchy, permanence in functioning and evolution, orientation to purpose, etc.

\section{References}

Bebbington, J., \& Thomson, I. (2013). Sustainable development, management and accounting: Boundary crossing. Management Accounting Research, 24(4), 277-283. http://dx.doi.org/10.1016/j.mar.2013.09.002

Bourne, M., Melnyk, S. A., Bititci, U., Platts, K., \& Andersen, B. (2014). Emerging issues in performance measurement. Management Accounting Research, 25(2), 117-118. http://dx.doi.org/10.1016/j.mar.2013.07.002

Ferreira, A., \& Otley, D. (2009). The design and use of performance management systems: An extended framework for analysis. Management Accounting Research, 263-282. http://dx.doi.org/10.1016/j.mar.2009.07.003

Hopwood, A. G. (2008). Management accounting research in a changing world. Journal of Management Accounting Research, 20, 3-13. http://dx.doi.org/10.2308/jmar.2008.20.1.3

Ittner, C. D., \& Larcker, D. F. (2002). Empirical managerial accounting research: Are we just describing management consulting practice? The European Accounting Review, 11(4), 787-794. http://dx.doi.org/10.1080/0963818022000047082

Janke, R., Matthias, D., \& Mahlendorf, J. W. (2014). An exploratory study of the reciprocal relationship between interactive use of management control systems and perception of negative external crisis effects. Management Accounting Research, 25(4), 251-270. http://dx.doi.org/10.1016/j.mar.2014.01.001

Matsui, K. (2013). Entry deterrence through credible commitment to transfer pricing at direct cost. Management Accounting Research, 24(3), 261-275. http://dx.doi.org/10.1016/j.mar.2013.01.001

Nixon, B., \& Burns, J. (2012). Strategic management accounting. Management Accounting Research, 23(4), 225-228. http://dx.doi.org/10.1016/j.mar.2012.09.005

Quinn, M. (2014). Stability and change in management accounting over time-A century or so of evidence from Guinness. Management Accounting Research, 25(1), 76-92. http://dx.doi.org/10.1016/j.mar.2013.06.001

Safiullin, L. N., Klychova, G. S., \& Zakirova, A. R. (2014). Information-Analitical Support of Cost Management in Horse Breeding. Mediterranean Journal of Social Sciences, 5(18), 193-196.

Soin, K., \& Collier, P. (2013). Risk and risk management in management accounting and control. Management Accounting Research, 24(2), 82-87. http://dx.doi.org/10.1016/j.mar.2013.04.003

\section{Copyrights}

Copyright for this article is retained by the author(s), with first publication rights granted to the journal.

This is an open-access article distributed under the terms and conditions of the Creative Commons Attribution license (http://creativecommons.org/licenses/by/3.0/). 